Article

\title{
Derived oil production by catalytic pyrolysis of scrap tires
}

\author{
Wei Li *, Chuanfeng Huang, Dapeng Li, Pengju Huo, Mingfeng Wang, Lei Han, Gang Chen, Huihui Li, \\ Xiaohong Li, Yongjuan Wang, Mengyan Wang \\ Hydro-carbon High-Efficiency Utilization Technology Research Center, Shaanxi Yanchang Petroleum (Group) Co., Ltd., Xi'an 710075, Shaanxi, China
}

\section{A R T I C L E I N F O}

Article history:

Received 20 November 2015

Accepted 23 January 2016

Published 5 April 2016

\section{Keywords:}

Scrap tire

Catalytic pyrolysis

Derived oil

Aromatic

\begin{abstract}
A B S T R A C T
Scrap tires were pyrolyzed in a continuously stirred batch reactor in the presence and absence of catalysts. The maximum yield of derived oil was up to $55.65 \mathrm{wt} \%$ at the optimum temperature, 500 ${ }^{\circ} \mathrm{C}$. The catalytic pyrolysis was performed using $1.0 \mathrm{wt} \%$ (on a scrap tire weight basis) of catalysts based on ZSM-5, USY, $\beta$, SAPO-11, and ZSM-22. The oil products were characterized using simulation distillation, elemental analysis, and gas chromatography-mass spectrometry. The results show that using a catalyst can increase the conversion of scrap tires to gas and decrease char by-products; the yield of derived oil remains unchanged or a little lower. The oils derived from catalytic pyrolysis had $\mathrm{H} / \mathrm{C}$ ratios of $1.55-1.65$ and contained approximately $70-75 \mathrm{wt} \%$ light oil, $0.3-0.58 \mathrm{wt} \% \mathrm{~S}$ and $0.78-1.0 \mathrm{wt} \% \mathrm{~N}$. Catalysts with high acid strengths and appropriate pore sizes, such as ZSM-5, USY, $\beta$, and SAPO-11, increased the amount of single-ring aromatics in the light-middle-fraction oil to 45 wt $\%$. The derived oil can therefore be used as a petrochemical feedstock for producing high-value-added chemical products or fuel oil.
\end{abstract}

(C) 2016, Dalian Institute of Chemical Physics, Chinese Academy of Sciences. Published by Elsevier B.V. All rights reserved.

\section{Introduction}

The amount of scrap tires is increasing significantly as a result of rapid economic growth and development of the transport industry. According to statistics [1,2], approximately 3.0 billion tires are generated globally, with a predicted growth rate of at least 1.0 billion tires each year. North America, Europe, and Asia generate a large number of scrap tires, accounting for almost $90 \%$ of global tire production. In China, more than 280 million tires were discarded in 2012, with a weight of 10.18 million tons. Scrap tires are insoluble and infusible thermosetting materials and are therefore difficult to degrade naturally. A lack of suitable techniques and economic factors had resulted in scrap tires becoming a serious problem in terms of environmental pollution. At present, the majority of scrap tires is deposited in open or landfill sites; this results in disposal problems and increases the risk of fires. Various recycling methods have been developed over the years, such as retreading, incineration, and crumbling to produce rubber powder, but they all have significant limitations or drawbacks.

Pyrolysis as a viable recycling process has potential advantages in terms of energy recovery and could mitigate the disposal problem [3]. The products of pyrolytic degradation of scrap tires could be reused as high-calorific-value gas to meet the energy requirements of processing plants, oil for boiler fuel, or high-value-added chemical feedstocks; the char formed could be used as low-grade activated carbon or carbon black. It has been proved that the derived oil is more suitable for making high-value-added chemicals than for use as fuel, because it contains large amounts of single-ring aromatics. Several workers have shown that the derived oil contains variable concentrations of valuable aromatic and aliphatic compounds such as

\footnotetext{
* Corresponding author. Tel: +86-13488473949; Fax:+86-29-89386230; E-mail: liwei142421@126.com

This work was supported by the Basic Research Program of VCC Technology (ycsy2014ky-A-14).

DOI: 10.1016/S1872-2067(15)60998-6 | http://www.sciencedirect.com/science/journal/18722067 | Chin. J. Catal., Vol. 37, No. 4, April 2016
} 
butadiene, D-limonene, benzene, toluene, and xylenes, which could be used directly as substitutes for conventional fuels or petrochemical feedstocks as a potential source of light aromatics [4-7]. San Miguel et al. [8] reported an increase in the yield of BTX aromatics, based on results obtained by incorporating in situ zeolites in the sample container of a thermobalance. This indicates that Diels-Alder dehydrogenation of alkanes to alkenes occurs, followed by cyclization and aromatization. This mechanism suggests that the steric and acidic properties of catalysts can be used to accelerate cyclization and aromatization reactions to increase the polyaromatic hydrocarbon content of the derived oil. Some researchers have found that the catalytic conversion of waste polymers in fixed-bed and semi-continuous fluidized-bed reactors significantly increases the concentration of single-ring aromatic species in the oil fraction $[9,10]$. Catalysts with strong acid sites and large pores, such as $\mathrm{Y}$ catalysts, produce more aromatics than are produced by ZSM-5 catalysts.

In this study, thermal pyrolysis of scrap tires at different temperatures and catalytic pyrolysis with various types of catalysts were performed in a nitrogen-purged stirred batch reactor. The effects of catalysts on the derived oils from scrap tires were investigated in terms of product yields, elemental compositions, simulation distillation, and hydrocarbon group composition using gas chromatography-mass spectrometry (GC-MS) analysis. Attention was principally focused on assessing methods for direct catalytic pyrolysis and studying the effects of catalysts on the reaction process and properties of the derived oil.

\section{Experimental}

\subsection{Materials and catalyst properties}

Sidewall rubber of automotive vehicle scrap tires ground to 20-100 mesh was supplied by a rubber-recycling company. The steel threads were removed prior to use by magnetic separation. Table 1 shows the ultimate and proximate analysis of the scrap tires. Table 2 lists the properties of the catalysts used in the work. The ZSM-5 and $\beta$ catalysts were provided by the Catalyst Plant of Nankai University, Tianjin, China. The USY, ZSM-22, and SAPO-11 catalysts were supplied by the College of
Table 1

Ultimate and proximate analysis of feedstock.

\begin{tabular}{lcc}
\hline Method & Material & Content (wt\%) \\
\hline Ultimate analysis & $\mathrm{C}$ & 83.34 \\
& $\mathrm{H}$ & 6.56 \\
$\mathrm{~S}$ & 1.33 \\
Proximate analysis & $\mathrm{N}$ & 0.79 \\
& $\mathrm{O}$ & 2.78 \\
& Ash & 4.20 \\
& Volatile matter & 63.04 \\
& Fixed carbon & 32.00 \\
& Moisture & 0.76 \\
\hline
\end{tabular}

Table 2

Physical properties of catalysts.

\begin{tabular}{lccc}
\hline Catalyst & $\mathrm{Si} / \mathrm{Al}$ & $S_{\text {BET }}\left(\mathrm{m}^{2} / \mathrm{g}\right)$ & Micropore size $(\AA)$ \\
\hline ZSM-5 & 30 & 541 & 5.6 \\
USY & 5.4 & 432.5 & 7.8 \\
$\beta$ & 73 & 524 & 6.5 \\
ZSM-22 & 58 & 350 & 5.6 \\
SAPO-11 & 4 & 186 & 6.7 \\
\hline
\end{tabular}

Chemistry and Chemical Engineering of the China University of Petroleum, Qingdao, China. The $\mathrm{Si} / \mathrm{Al}$ atomic ratios of the catalysts were determined using inductively coupled plasma atomic emission spectroscopy (Leeman Prodigy XP ICP-AES spectrometer). Surface areas were determined at $-196{ }^{\circ} \mathrm{C}$ using a Micromeritics ASAP 2020 nitrogen gas adsorption analyzer.

\subsection{Reaction apparatus}

The experiments were performed in a 1000-mL static stirred batch stainless-steel reactor, using $150 \mathrm{~g}$ of scrap tires and $1.5 \mathrm{~g}$ of catalyst (Fig. 1). The reactor was heated externally with an electric heating jacket to the desired temperature at a heating rate $15{ }^{\circ} \mathrm{C} / \mathrm{min}$, and the temperature was held for 30 min until no liquid was produced. $\mathrm{N}_{2}(400 \mathrm{~mL} / \mathrm{min})$ was used as the purging gas to carry volatile matter away from the hot zone and downward into a first condenser, which was cooled with ice-water mixtures, and then into a second water-cooled condenser, which was used to condense out the heavy and light fractions. The non-condensable gases were collected in sample bags for off-line GC analysis. Trace water and particles were

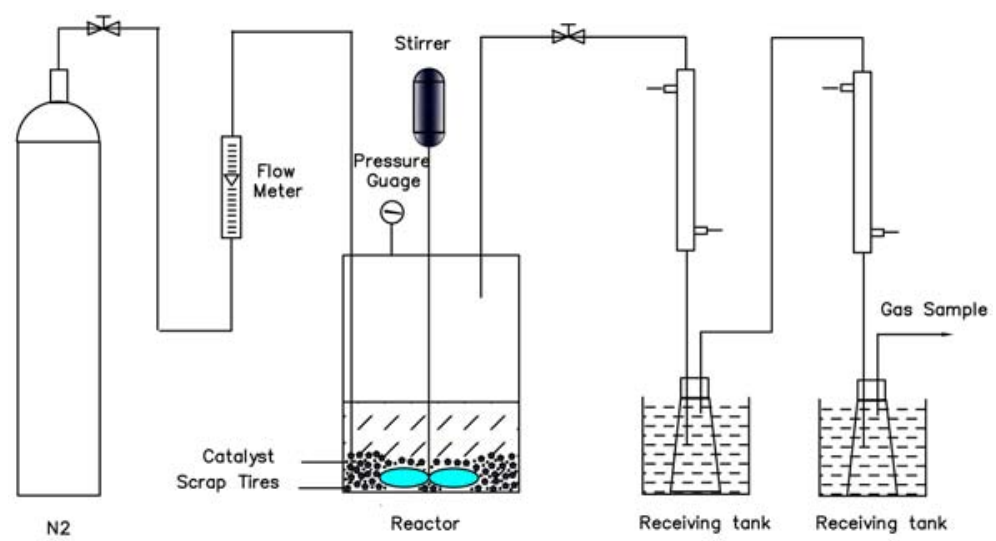

Fig. 1. Schematic diagram of the scrap tire pyrolysis system. 
removed from the liquid sample prior to analysis.

The oil condensed in the oil-receiving tank was weighed directly, and the char left in the bottom of the reactor was collected and weighed by subtracting the weight of the catalyst. The weight of the gas products was calculated as the difference between the loaded amount of scrap tires minus the weights of derived oil and char after the end of each experiment. The yields of derived oil, char, and gas were then calculated.

\subsection{Product analysis}

The derived oils were analyzed with a GC-simulated distillation apparatus (Agilent 7890B) using standard method ASTM 2887 to obtain boiling range data. The data are as follows: gasoline fraction, initial boiling point to $180{ }^{\circ} \mathrm{C}$, diesel fraction $180-350{ }^{\circ} \mathrm{C}$ and heavy oil $350{ }^{\circ} \mathrm{C}$ to final boiling point. In the experiment, the total gasoline and diesel fractions were defined as light oil.

The elemental composition, i.e., H, C, and N contents of the derived oil, was determined using an elemental analyzer (AJ13-std-EA5000). The S content was obtained based on ultraviolet fluorescence (Shimadzu UV-2700) according to the ASTM D5453 method, and the 0 content was calculated by difference.

The chemical groups in the derived oil were identified using GC-MS (Agilent 7890). The analysis was performed using a Thermo Fisher ITO 1100 GC-MS system at an ionizing energy of $70 \mathrm{eV}$. The evolved species were identified based on their mass spectra in the National Institute of Standards and Technology MS library and by comparing their elution times with those of pure commercial compounds.

\section{Results and discussion}

\subsection{Thermal pyrolysis}

Scrap tires are composed of carbon atoms linked by single or double bonds to form a three-dimensional structure with a bulk mass; they are very difficult to degrade and handle because of the degradation-inhibiting fillers used in tire manufacturing. Pyrolysis, which is a thermochemical process, can transform scrap tires into high-value chemical products and increase their reuse value.

The effect of temperature, a key factor in scrap tire pyrolysis, was investigated. Figure 2 shows the effect of temperature on the product distribution for scrap tire pyrolysis. The reaction temperature significantly affected the product distribution. As the temperature increased from 430 to $500{ }^{\circ} \mathrm{C}$, the gas yield decreased from 8.00 to $4.50 \mathrm{wt} \%$. The highest yield of char was $48.67 \mathrm{wt} \%$ at $430{ }^{\circ} \mathrm{C}$, which implies that pyrolysis was incomplete at low temperatures. The char yield gradually decreased to $40.0 \mathrm{wt} \%$ as the temperature rose to $470{ }^{\circ} \mathrm{C}$, and then remained constant above $470{ }^{\circ} \mathrm{C}$. The yield of derived oil was $43.33 \mathrm{wt} \%$ at $430{ }^{\circ} \mathrm{C}$ and increased significantly to $53.5 \mathrm{wt} \%$ at $470{ }^{\circ} \mathrm{C}$ and $55.5 \mathrm{wt} \%$ at $500{ }^{\circ} \mathrm{C}$. The best results were achieved at $500{ }^{\circ} \mathrm{C}$ with yields of gas, derived oil, and char of $4.50,55.5$, and $40.0 \mathrm{wt} \%$, respectively. This is consistent with previous

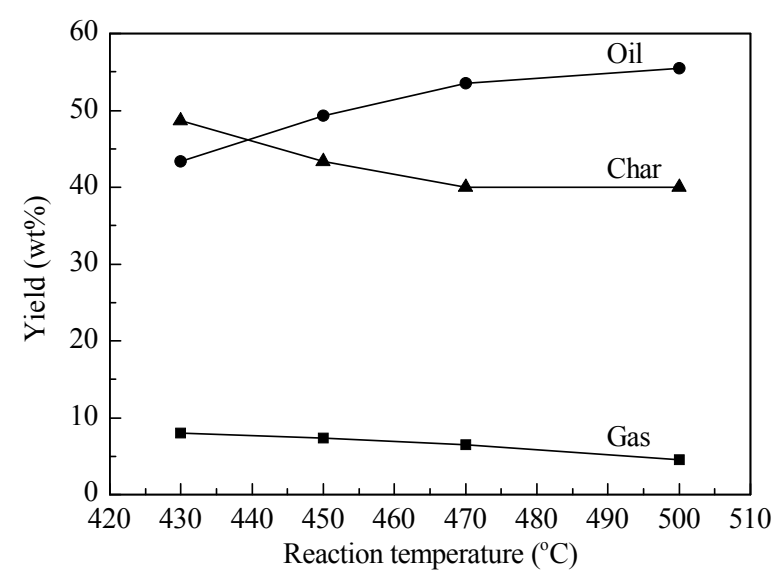

Fig. 2. Effect of pyrolysis temperature on product distribution.

reports that the maximum amount of pyrolytic oil was obtained in the range $400-550{ }^{\circ} \mathrm{C}[6,11-16]$. Berrueco et al. [17] obtained a maximum liquid yield at $500{ }^{\circ} \mathrm{C}$. Laresgoiti et al. [18] studied the pyrolysis of scrap tires in the range $300-700{ }^{\circ} \mathrm{C}$ and found that increasing temperature above $500{ }^{\circ} \mathrm{C}$ had almost no effect on the pyrolysis reaction.

\subsection{Catalytic pyrolysis}

The use of a catalyst generally promotes the pyrolysis of scrap tires and improves the yields or upgrades the properties of the products to obtain desired chemicals for specific applications. It also increases the reaction rate and shortens the reaction time.

Table 3 shows the product distributions for catalytic and thermal pyrolysis at $500{ }^{\circ} \mathrm{C}$. The catalysts had a limited effect on the yield of derived oil, whereas the gas yield increased and that of char decreased significantly. The yields of gas, derived oil, and char were 4.50, 55.5, and $40.0 \mathrm{wt} \%$, respectively, for thermal pyrolysis. However, for catalytic pyrolysis, the gas yield increased to $6.17-10.45 \mathrm{wt} \%$, twice that of thermal pyrolysis, and the char yield decreased to $34.43-38.71 \mathrm{wt} \%$. A reasonable explanation is that catalytic pyrolysis may involve two stages. First, at low temperatures, the scrap tire powder is liquefied to give a mixture of liquid hydrocarbons and solid carbon black, with only a little degradation of lower-boiling-point components. Second, as the reaction temperature gradually increases, the liquid hydrocarbons come into contact with active sites on the catalyst and react quickly, shortening the overall reaction time. As a result, condensation of coke on the surfaces of carbon black and the catalyst is inhibited. Therefore, although addition of a catalyst during py-

Table 3

Product distributions (wt\%) for catalytic and thermal pyrolysis.

\begin{tabular}{lccc}
\hline Catalyst & Gas & Derived oil & Char \\
\hline ZSM-5 & 6.49 & 55.65 & 37.86 \\
USY & 9.97 & 53.49 & 36.54 \\
$\beta$ & 8.24 & 54.00 & 37.76 \\
SAPO-11 & 10.45 & 55.12 & 34.43 \\
ZSM-22 & 6.17 & 55.12 & 38.71 \\
None & 4.50 & 55.50 & 40.00 \\
\hline
\end{tabular}


rolysis does not significantly increase the yield of derived oil, it promotes the deep transformation of scrap tires into organic hydrocarbons in a shorter reaction time.

The SAPO-11 catalyst gave the highest yield of gas, 10.45 $\mathrm{wt} \%$ and the lowest yield of char $34.43 \mathrm{wt} \%$. This proves that the scrap tires were completely converted and formed less carbonaceous coke, approximately $2.5 \mathrm{wt} \%$, compared with the amount of fixed carbon, $32 \mathrm{wt} \%$, in scrap tire compounds. However, the highest yield of derived oil, $55.65 \mathrm{wt} \%$, was obtained with the ZSM-5 catalyst, with a gas yield of $6.49 \mathrm{wt} \%$. The order of the gas yields obtained with different catalysts was SAPO-11 > USY > $\beta>$ ZSM-5 > ZSM-22 > no catalyst. The order of the oil yields was ZSM-5 $>$ no catalyst $>$ SAPO-11 = ZSM-22 $>\beta>$ USY. The order of the char yields was no catalyst $>$ ZSM-22 > ZSM-5 > $\beta>$ USY > SAPO-11. These results reflect the effects of the catalyst on scrap tire pyrolysis: catalysts with high surface areas and strong acidity accelerate the conversion of scrap tires and produce much more low-molecular hydrocarbons. Research on the catalytic conversion of polyolefin plastics to petrochemical feedstock has shown that acidic catalysts significantly increase the amounts of gaseous hydrocarbons produced $[19,20]$.

\subsubsection{Elemental analysis}

In the presence of a catalyst, the oil derived from catalytic pyrolysis is brown, with a low viscosity and good fluidity; this implies that the oil has a relatively high content of light fraction. In the absence of a catalyst, the oil obtained from the thermal process is dark brown, with a higher viscosity. Table 4 presents the elemental analysis results for the derived oils obtained from catalytic and thermal pyrolysis.

The $\mathrm{H}, \mathrm{O}$, and $\mathrm{S}$ contents of the oil derived from thermal pyrolysis were $10.164,3.401$, and $0.602 \mathrm{wt} \%$, respectively. The presence of $1.0 \mathrm{wt} \%$ catalyst clearly improved the quality of the derived oil. For example, the addition of a ZSM-5 catalyst increased the $\mathrm{H}, \mathrm{S}$, and $\mathrm{O}$ contents to $11.214,0.341$, and 1.327 $w t \%$, respectively. The derived oils had low $\mathrm{S}$ contents of $0.3-0.57 \mathrm{wt} \%$ and high $\mathrm{N}$ contents of $0.7-1.0 \mathrm{wt} \%$ in the presence and absence of catalysts, respectively, in contrast to other reported results. López et al. [21] studied the properties of oils derived from the pyrolysis of granulated scrap tires at moderate temperature $550{ }^{\circ} \mathrm{C}$ in a pilot distillation unit. They found that the derived oil had a lower $\mathrm{S}$ and $\mathrm{N}$ contents of $0.4 \mathrm{wt} \%$ and $0.6 \mathrm{wt} \%$, respectively. Some researchers have reported that the $\mathrm{S}$ concentration in the oil ranges from 0.9 to $1.4 \mathrm{wt} \%$. The results can be attributed to catalytic reactions of the primary pyrolysis products of scrap tires, which accelerate $\mathrm{C}-\mathrm{S}$,

\section{Table 4}

Elemental analysis results (wt\%) for derived oils obtained from catalytic and thermal pyrolysis.

\begin{tabular}{lcccccc}
\hline Catalyst & $\mathrm{C}$ & $\mathrm{H}$ & $\mathrm{S}$ & $\mathrm{N}$ & $\mathrm{O}$ & $\mathrm{H} / \mathrm{C}$ \\
\hline ZSM-5 & 86.333 & 11.214 & 0.341 & 0.786 & 1.327 & 1.559 \\
USY & 85.801 & 11.431 & 0.535 & 0.990 & 1.243 & 1.599 \\
$\beta$ & 84.134 & 11.155 & 0.381 & 0.833 & 3.497 & 1.591 \\
SAP0-11 & 84.115 & 11.118 & 0.393 & 0.845 & 3.529 & 1.586 \\
ZSM-22 & 84.755 & 11.666 & 0.547 & 1.028 & 2.003 & 1.652 \\
None & 85.202 & 10.164 & 0.602 & 0.830 & 3.401 & 1.432 \\
\hline
\end{tabular}

$\mathrm{C}-\mathrm{N}$, and $\mathrm{C}-\mathrm{O}$ bond cleavage on the surface acid sites of the catalysts; this removes heteroatoms in the derived oils. In addition, zinc oxide acts as an accelerant, which can control the vulcanization process and enhance the physical properties of the rubber and the desulfurization reaction. Some research has indicated that zinc oxide promotes the hydrogenation of thiophene rings to generate hydrocarbon sulfides, which can produce stable zinc sulfide, significantly decreasing the $\mathrm{S}$ content.

\subsubsection{Distillation}

The derived oil was separated from the product mixture after each pyrolysis using a solid-liquid separation method. The derived oil was analyzed using a GC simulation distillation apparatus.

Figure 3 shows the distillation data for the derived oils obtained from catalytic and thermal pyrolysis. Their boiling points ranged between 27 and $520{ }^{\circ} \mathrm{C}$; this is a much wider range than that of previously reported data $\left(70-400{ }^{\circ} \mathrm{C}\right)$. The results show that the gasoline fraction accounted for 23-38 $w t \%$, the diesel fraction for 35-38 wt $\%$, and the heavy oil fraction for 1.0-3.0 wt\%. However, the derived oil from thermal pyrolysis had a lower gasoline fraction, $20.0 \mathrm{wt} \%$ and higher diesel fraction, $37.4 \mathrm{wt} \%$. The catalyst significantly affects the conversion of primary products to light hydrocarbons, but acidic and sterically bulky catalysts promote the cracking of large molecules to small molecules, and this increases the gasoline fraction at the expense of the diesel fraction. Additionally, close inspection of the distillation-temperature curves for all the catalysts (Fig. 3) shows that ZSM-22 gave $60.0 \mathrm{wt} \%$ light-fraction oil and 30-35 wt\% middle-fraction oil, but for the other catalysts (ZSM-5, USY, $\beta$, and SAPO-11), the values were 70-75 and 25-27 wt\%, respectively. This might be because of the weak-medium acidity and smaller pore size of ZSM-22.

The derived oil can be directly used as boiler fuel or heating oil after separation, purification, and hydrotreatment. Murillo et al. [22] showed a process for separation of valuable gas and liquid fraction from the volatiles released in scrap tire pyrolysis by using commercial process simulation software. Five streams were obtained and characteristics by comparing its different boiling points with commercial fuels. The first stream (7.4

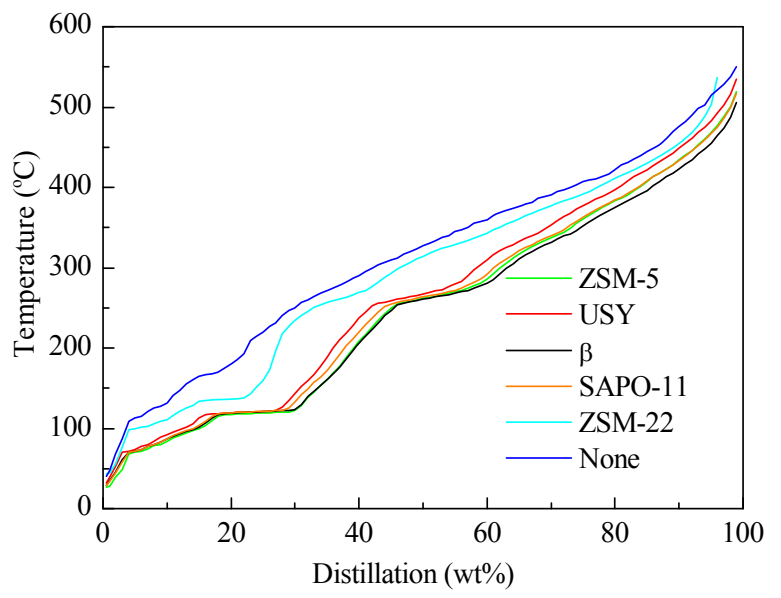

Fig. 3. Distillation data for derived oils obtained from catalytic and thermal pyrolysis. 
Table 5

GC-MS analysis (wt\%) of derived oils obtained from catalytic and thermal pyrolysis.

\begin{tabular}{|c|c|c|c|c|c|c|c|c|c|c|c|c|}
\hline Catalyst & Alkanes & $\begin{array}{l}\text { Alkylben- } \\
\text { zenes }\end{array}$ & Indans & Indenes & $\begin{array}{c}\text { Single ring } \\
\text { aromatics }\end{array}$ & $\begin{array}{l}\text { Naphtha- } \\
\text { lene }\end{array}$ & $\begin{array}{c}\text { Naphtha- } \\
\text { lenes }\end{array}$ & $\begin{array}{l}\text { Acenaph- } \\
\text { thenes }\end{array}$ & $\begin{array}{l}\text { Acenaph- } \\
\text { thylenes }\end{array}$ & $\begin{array}{c}\text { Double ring } \\
\text { aromatics }\end{array}$ & $\begin{array}{l}\text { Three ring } \\
\text { aromatics }\end{array}$ & $\begin{array}{c}\text { Total } \\
\text { aromatics }\end{array}$ \\
\hline ZSM-5 & 49.7 & 33.3 & 5.1 & 7.4 & 45.8 & 0.4 & 2.5 & 1.1 & 0.3 & 4.3 & 0.2 & 50.3 \\
\hline USY & 51.1 & 35.8 & 3.0 & 6.6 & 45.4 & 0.3 & 2.0 & 1.0 & 0.1 & 3.4 & 0.1 & 48.9 \\
\hline$\beta$ & 49.9 & 39.8 & 2.0 & 4.9 & 46.7 & 0.2 & 1.8 & 1.0 & 0.3 & 3.3 & 0.1 & 50.1 \\
\hline SAPO-11 & 51.5 & 42.5 & 0.7 & 3.6 & 46.8 & 0.0 & 0.9 & 0.6 & 0.0 & 1.5 & 0.2 & 48.5 \\
\hline ZSM-22 & 57.3 & 34.1 & 1.8 & 3.2 & 39.1 & 0.5 & 2.4 & 0.6 & 0.0 & 3.5 & 0.1 & 42.7 \\
\hline None & 52.9 & 34.4 & 0.4 & 5.7 & 40.5 & 0.3 & 4.0 & 2.2 & 0.1 & 6.6 & 0.0 & 47.1 \\
\hline
\end{tabular}

$w t \%)$ showed similar characteristics with light naphtha (boiling point range $\left.61.5-107.5^{\circ} \mathrm{C}\right)$. The second stream (22.37 wt\%) was comparable to commercial naphtha $\left(146.4-199.5^{\circ} \mathrm{C}\right)$. The third stream (15.18 wt\%) coincided with No. 1 fuel oil regarding boiling point range, flash point, and $\mathrm{S}$ content. The last two fractions were classified as heavy gas oil according to their boiling point $\left(305.1-363.3{ }^{\circ} \mathrm{C}\right.$ and $335.3-374.4{ }^{\circ} \mathrm{C}$, respectively). Conventional diesel fuels have a cetane number between 40 and 55 while scrap tire liquid has showed value between 40 and 44 [23]. In addition, the octane number of the obtained naphtha was higher than that of petroleum naphtha. The light fraction was suitable as a gasoline additive, the middle fraction could be used as a plasticizer for reducing the cure times of rubbers, and the heavy fraction had potential applications in coke production and road materials.

\subsubsection{GC-MS analysis}

The derived oils are complex mixtures, consisting of a wide variety of aliphatic, aromatic, and polar compounds; this reflects the tire compositions, organic additives, and tire pyrolysis products. Scrap tires consist of natural rubber and synthetic rubber, which are derived from petroleum products such as butyl rubber and styrene-butadiene rubber. Rubber decomposition involves breakage of the $\mathrm{C}-\mathrm{C}$ bonds in the polymer network structure and production of reactive free radicals, which can participate in reactions such as isomerization, dehydrogenation, aromatization, and condensation. As a result, the derived oils not only have a wide distillation range, but also display the features of higher single-ring aromatic and polycyclic aromatic hydrocarbon species [24]. It is therefore essential to acquire more detailed information on the compositions of the derived oils using GC-MS analysis.

The alkanes and aromatic compounds in the derived oils obtained from catalytic and thermal pyrolysis at $500{ }^{\circ} \mathrm{C}$ are listed in Table 5. The results show that the oils contained mainly alkanes, single-ring aromatics, and double-ring aromatics, with much less three-ring aromatics in the oil fraction (distilled up to $350^{\circ} \mathrm{C}$ ). The results also show that the catalysts had a significant effect on the product composition, by promoting isomerization, cyclization, and aromatization of the primary products, which are the main sub-units of the original rubber molecules, and decreasing the amount of straight-chain alkenes; the content of straight-chain alkanes was $3.5 \mathrm{wt} \%$ for thermal pyrolysis. This can be explained by conversion of the straight-chain alkanes to cycloalkanes or aromatics via cyclization and aromatization reactions at the acidic sites, and the shape selectivities of the catalysts. The pyrolysis of polyethylene without a catalyst generates $n$-alkanes and $n$-alkenes [25]. The ZSM-22 catalyst has weak-medium acidity and low activity in both isomerization and aromatization; this led to a higher alkane content, $57.3 \mathrm{wt} \%$. However, the catalysts with medium-strong acidities (such as ZSM-5, USY, $\beta$, and SAPO-11) enhance cyclization and dehydrogenation to form aromatics species, therefore the alkane contents were lower than that obtained with ZSM-22.

The acidity and size of the catalyst can affect the conversion of alkanes to aromatic hydrocarbons, therefore the aromatics were analyzed in detail. Again, because of the properties of ZSM-22 mentioned above, the derived oil obtained using this catalyst gave the lowest content of single-ring aromatics (39.1 wt $\%)$. The $\beta$ and SAPO- 11 catalysts gave the best experimental results; they have medium-strong acidities and large pores, and therefore gave the highest contents of alkylbenzenes, i.e., 39.8 wt $\%$ and 42.5 wt $\%$, respectively; USY, ZSM-22, ZSM-5, and thermal pyrolysis gave similar aromatic contents. Laresgoiti et al. [18] performed pyrolysis under nitrogen in a $3.5-\mathrm{dm}^{3}$ autoclave at $300-700{ }^{\circ} \mathrm{C}$. They found that the derived oils from scrap tire pyrolysis were a complex mixture of $\mathrm{C}_{6}-\mathrm{C}_{24}$ organic compounds with aromatic contents of 53.4-74.8 wt\%. The amounts of double-ring aromatic compounds in the derived oils were lower in the presence of catalysts than without catalysts. This is because the catalyst can trigger side-chain cleavage reactions on the catalyst surface, leading to a decrease in the amount of double-ring aromatics.

\section{Conclusions}

The thermal and catalytic pyrolysis of scrap tires using different types of catalysts was investigated. Compared with the thermal process, the addition of a catalyst increased the reaction rate, shortened the reaction time, increased the conversion of scrap tires, decreased the char yield, and increased the gas yield; the yield of derived oil was unchanged or a little lower. Catalytic pyrolysis gave better-quality derived oils with higher light oil yields (approximately 70-75 wt\%), H/C ratios $(1.55-1.65)$, and lower contents of $\mathrm{S}(0.3-0.58 \mathrm{wt} \%)$ and $\mathrm{N}$ (0.78-1.0 wt\%). The acidity and pore size of the catalyst affected the chemical composition of the derived oil. In the presence of ZSM-5, USY, $\beta$, and SAPO-11, the total amounts of aromatic compounds in the derived oils were significantly higher, up to $50.0 \mathrm{wt} \%$, and the contents of single-ring aromatics reached $45 \mathrm{wt} \%$. 


\section{Graphical Abstract}

Chin. J. Catal., 2015, 36: 526-532 doi: 10.1016/S1872-2067(15)60998-6

\section{Derived oil production by catalytic pyrolysis of scrap tires}

Wei Li *, Chuanfeng Huang, Dapeng Li, Pengju Huo, Mingfeng Wang, Lei Han, Gang Chen, Huihui Li, Xiaohong Li, Yongjuan Wang, Mengyan Wang

Shaanxi Yanchang Petroleum (Group) Co., Ltd.

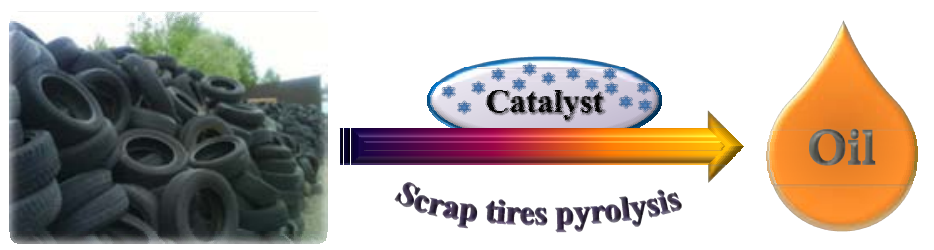

Thermal and catalytic pyrolysis of scrap tires was performed in a continuously stirred batch reactor at various temperatures using different catalysts. The addition of a catalyst significantly increased the yield of light oil and the content of light aromatics in the derived oil from scrap tires.

\section{References}

[1] B. Z. Qian, J. F. Zhu, Rubber Plast. Resour. Utili., 2010, (4), 30-41.

[2] J. H. Yan, Y. L. Gao, Z. X. Zhang, Y. Chi, K. F. Cen, J. Fuel Chem. Technol., 2003, 31, 589-594.

[3] P. T. Williams, A. J. Cunliffe, A. J. Brindle, J. Engery Inst., 2001, 74, 100-112.

[4] S. Q. Li, Q. Yao, Y. Chi, J. H. Yan, K. F. Cen, Ind. Eng. Chem. Res., 2004, $43,5133-5145$.

[5] P. T. Williams, A. J. Brindle, Waste Manage Res., 2002, 20 546-555.

[6] P. T. Williams, A. J. Brindle, Fuel, 2003, 82, 1023-1031.

[7] J. A. Conesa, I. Martín-Gullón, R. Font, J. Anal. Appl. Pyrolysis., 2005, 74, 265-269.

[8] G. San Miguel, J. Aguado, D. P. Serrano, J. M. Escola, Appl. Catal. B, 2006, 64, 209-219.

[9] P. T. Williams, A. J. Brindle, J. Anal. Appl. Pyrolysis., 2003, 67, 143-164.

[10] P. T. Williams, A. J. Brindle, Fuel, 2002, 81, 2425-2434.

[11] E. Aylón, A. Fernández-Colino, R. Murillo, M. V. Navarro, T. García, A. M. Mastral, Waste Manage, 2010, 30, 1220-1224.

[12] A. M. Mastral, R. Murillo, M. S. Callén, T. García, C. E. Snape, Energy Fuel, 2000, 14, 739-744.

[13] R. Murillo, E. Aylón, M. V. Navarro, M. S. Callén, A. Aranda, A. M.
Mastral, Fuel Processing Technol., 2006, 87, 143-147.

[14] S. Baumlin, F. Broust, M. Ferrer, N. Meunier, E. Marty, J. Lede, Chem. Eng. Sci., 2005, 60, 41-55.

[15] W. J. Hall, P. T. Williams, J. Anal. Appl. Pyrolysis., 2008, 81, 139-147.

[16] T. Miyazawa, T. Kimura, J. Nishikawa, S. Kado, K. Kunimori, K. Tomishige, Catal.Today, 2006, 115, 254-262.

[17] C. Berrueco, E. Esperanza, F. J. Mastral, J. Ceamanos, P. García-Bacaicoa, J. Anal. Appl. Pyrolysis., 2005, 74, 245-253.

[18] M. F. Laresgoiti, B. M. Caballero, I. De Marco, A. Torres, M. A. Cabrero, M. J. Chomón, J. Anal. Appl. Pyrolysis., 2004, 71, 917-934.

[19] D. P. Serrano, J. Aguado, J. M. Escola, J. M. Rodriguez, G. San Miguel, J. Anal. Appl. Pyrolysis., 2005, 74, 370-378.

[20] D. P. Serrano, J. Aguado, J. M. Escola, E. Garagorri, J. M. Rodríguez, L. Morselli, G. Palazzi, R. Orsi, Appl. Catal. B, 2004, 49, 257-265.

[21] F. A. López, T. A. Centeno, F. J. Alguacil, B. Lobato, J. Hazard Mater., 2011, 190, 285-292.

[22] R. Murillo, A. Aranda, E. Aylón, M. S. Callén, A. M. Mastral, Ind. Eng. Chem. Res., 2006, 45, 1734-1738.

[23] M. R. Islam, H. Hiroyuki, A. R. Beg, T. Kazunori, Int. J. Elec. Power, 2008, 6, 1359.

[24] H. Pakdel, D. M. Pantea, C. Roy, J. Anal. Appl. Pyrolysis., 2001, 57, 91-107.

[25] J. Schirmer, J. S. Kim, E. Klemn, J. Anal. Appl. Pyrolysis., 2001, 60, 205-217.

\section{催化热解废轮胎制衍生油}

李 伟, , 黄传峰, 李大鹏, 霍鹏举, 王明峰, 韩 磊, 陈 刚, 李慧慧, 李晓宏, 王永娟, 王孟艳 陕西延长石油(集团)有限责任公司碳氢高效利用技术研究中心，陕西西安710075

摘要: 催化热解废轮胎对于资源利用及环境保护具有重要意义, 近年来引起人们关注. 在废轮胎胶粉热解反应中加入催化剂, 不 仅会加速胶粉裂解速率, 缩短反应时间, 而且可以通过催化剂择形催化改变产物分布, 从而提高目的产物衍生油的收率和性能. 国内外对废轮胎催化热解已做了大量研究, 以期提高衍生油中高附加值单环芳烃的含量, 同时降低 $\mathrm{S}, \mathrm{N}$ 和 $\mathrm{Cl}$ 含量, 虽然已取得较 大进展, 但衍生油收率较低, 大大降低了该技术的可行性.

本文采用带搅拌器的 $1000 \mathrm{~mL}$ 不锈钢反应器, 在常压条件下研究了反应温度和催化剂类型对废轮胎胶粉热解反应及产物衍生 油性能的影响, 通过元素分析、馏程模拟和色谱-质谱等表征手段检测了衍生油的理化性能. 结果表明, 在废轮胎胶粉热解反应过 
程中, 随反应温度上升, 出油速率先增加后降低. 至 $500{ }^{\circ} \mathrm{C}$ 时, 热解衍生油收率最高达 $55.65 \mathrm{wt} \%$, 所得衍生油呈黑棕色, 具有轻质 油含量低、 $\mathrm{S}$ 和 $\mathrm{N}$ 含量高、粘度低和流动性好的特点, 其轻质芳烃含量低, 却含有大量可以转变为芳烃的脂肪烃类. 因此, 为了提高 衍生油中轻质油和轻质芳烃收率, 降低 $\mathrm{S}$ 和 $\mathrm{N}$ 含量, 尽量维持较高的衍生油收率, 在热解反应过程中引入少量ZSM- $5, \mathrm{USY}, \beta$, SAPO-11和ZSM-22等常见催化剂, 利用催化剂独特的孔道结构和酸分布, 达到定向催化和转化的目的, 提高轻质芳烃含量. 同时, 为了克服催化剂与胶粉难以接触进行反应的问题, 在反应温度升至 $200{ }^{\circ} \mathrm{C}$ 时, 维持一定时间保证胶粉发生溶胀和液化反应形成液 体烃类, 使得催化剂不仅能够均匀分散于液体烃中与其接触进行反应, 而且有效提高了反应物料与催化剂之间传质传热效率, 使 得裂解反应在均相中进行, 降低因传热不均匀而造成的结焦和过度裂化反应. 在催化热解过程中, $1.0 \mathrm{wt} \%$ 催化剂的加入可明显缩 短反应时间, 在保证衍生油收率基本不变的情况下, 获得的衍生油呈黄棕色, 轻质油收率较高为 $70-75 \mathrm{wt} \%, \mathrm{~S}$ 和 $\mathrm{N}$ 含量分别降至 $0.3-0.58 \mathrm{wt} \%$ 和 $0.78-1.0 \mathrm{wt} \%$. 以具有较高酸性和孔径分布的ZSM- 5 , USY, $\beta$ 和SAPO- 11 为催化剂时, 衍生油中总芳烃含量可达到 $50 \mathrm{wt} \%$, 其中单环芳烃含量高达 $45 \mathrm{wt} \%$.

关键词: 废轮胎; 催化热解; 衍生油; 芳烃

收稿日期: 2015-11-23. 接受日期: 2016-01-20. 出版日期: 2016-04-05.

*通讯联系人. 电话: 13488473949; 传真: (029)89386230; 电子信箱: liwei142421@126.com

基金来源: 延长石油集团VCC配套技术研发项目(ycsy2014ky-A-14).

本文的英文电子版由Elsevier出版社在ScienceDirect上出版(http://www.sciencedirect.com/science/journal/18722067). 